\title{
Article \\ Biochar Rescues Native Trees in the Biodiversity Hotspot of Mauritius
}

\author{
Leeladarshini Sujeeun (D) and Sean C. Thomas *(D)
}

check for

updates

Citation: Sujeeun, L.; Thomas, S.C. Biochar Rescues Native Trees in the Biodiversity Hotspot of Mauritius. Forests 2022, 13, 277. https:/ / doi.org/10.3390/f13020277

Academic Editor: Qinfeng Guo

Received: 30 December 2021

Accepted: 5 February 2022

Published: 9 February 2022

Publisher's Note: MDPI stays neutral with regard to jurisdictional claims in published maps and institutional affiliations.

Copyright: (c) 2022 by the authors. Licensee MDPI, Basel, Switzerland. This article is an open access article distributed under the terms and conditions of the Creative Commons Attribution (CC BY) license (https:/ / creativecommons.org/licenses/by/ $4.0 /)$.

\author{
Institute of Forestry and Conservation, University of Toronto, 33 Willcocks St., Toronto, ON M5S 3B3, Canada; \\ lutchmee.sujeeun@mail.utoronto.ca \\ * Correspondence: sc.thomas@utoronto.ca; Tel.: +1-416-978-1044
}

\begin{abstract}
Many tropical invasive species have allelopathic effects that contribute to their success in native plant communities. Pyrolyzed biomass ("biochar") can sorb toxic compounds, including allelochemicals produced by invasive plants, potentially reducing their inhibitory effects on native species. Strawberry guava (Psidium cattleianum) is among the most important allelopathic invasive species on tropical islands and recognized as the most serious threat among invasive species in the global biodiversity hotspot of Mauritius. We investigated the effects of additions of locally produced biochar on native tree species in a field experiment conducted in areas invaded by strawberry guava within Mauritius' largest national park. Growth and survivorship of native tree species were monitored over 2.5 years in plots subjected to four treatments: non-weeded, weeded, weeded $+25 \mathrm{t} /$ ha biochar, and weeded $+50 \mathrm{t} /$ ha biochar. Native tree growth and survivorship were strongly suppressed by strawberry guava. Biochar treatments dramatically increased native tree performance, with more than a doubling in growth, and substantially increased native tree survivorship and species diversity, while suppressing strawberry guava regeneration, consistent with growth-promoting properties and sorption of allelochemicals. We conclude that biochars, including "sustainable biochars" produced from locally accessible biomass using low-tech pyrolysis systems, have considerable potential to counteract effects of allelopathic invaders and increase the capacity for native species regeneration in tropical island ecosystems.
\end{abstract}

Keywords: allelopathy; biochar; invasive species; island ecosystems; Psidium cattleianum

\section{Introduction}

The global success of non-native invasive plants is often attributed to the lack of natural enemies that allow them to fully exploit their potential for resource competition and displace native species [1]. Recent studies support an alternative theory that many exotic species may benefit from ecological advantages of "novel chemistry" via allelopathy outside their native range [1,2]. Allelochemical interference can contribute to the dominance of an invader in its introduced habitat [3]; allelopathy is estimated to be present in more than half of invasive plants globally [4], including many of the most notorious cases [1], such as Imperata cylindrica, Lantana camara, and Chromolaena odorata, that are copious producers of allelochemicals having strong inhibitory effects on native plant species [5-7]. Psidium cattleianum Sabine (Myrtaceae) is likewise a highly invasive species that forms dense monotypic stands [8] and can suppress native vegetation by releasing allelochemicals into the soil [9-11]. Invasive plant species such as $P$. cattleianum have a high potential for expanding their range in tropical biodiversity hotspots and threatening plant diversity globally [12]. The negative impacts of invasive species on native biota are increasing rapidly [13], particularly in tropical island ecosystems where ecological impacts are most acute due to limited habitat area, poor competitive ability of native species, and putative vacant niches [14].

Psidium cattleianum (strawberry guava) is one of the world's 36 most invasive plant species [12] and has been widely introduced to tropical islands on account of its edible 
fruit [10]. Outside its native range in Brazil, strawberry guava has had serious impacts on tropical forest ecosystems in Mauritius and Hawaii, threatening native flora and fauna, particularly rare and endangered endemic species $[8,15]$. The native forests of Mauritius exist only as isolated fragments that are increasingly dominated by strawberry guava [15]. This species' success can be attributed to competitive traits, such as high reproductive capacity, clonal growth, resprouting ability, and tolerance of a wide range of light conditions $[8,16]$. In addition, strawberry guava has a deep rooting system that can lower the water table, reducing flow in streams and groundwater systems, with negative impacts on native trees [10]. In the lowland wet forests of Mauritius and Hawaii, native plant regeneration is particularly constrained by high densities of strawberry guava $[9,17-19]$. Mauritius is part of the globally significant Mascarene biodiversity hotspot [20,21], with almost 700 native angiosperm species, of which $39.5 \%$ are endemic to the island. Over $80 \%$ of the endemic flora is threatened by the invasion of introduced species such as strawberry guava [22], and there is an urgent need to restore the native forest communities.

Allelopathy has long been suspected to facilitate the invasion of strawberry guava and contribute to its dominance in the upland forests of Mauritius [10,23]. A recent study showed that strawberry guava releases allelochemicals from its leaves [24] that may contribute to its success by inhibiting the germination and growth of native plant species. Allelopathic compounds such as $\beta$-caryophyllene, $\alpha$-pinene and phenolics have been identified in strawberry guava leaves and fruits $[10,11]$. $\beta$-caryophyllene is the primary constituent in strawberry guava leaf oils [25] that has been shown to inhibit the growth of tomato, radish, and mungbean seedlings [26]. Inhibitory effects have also been shown for $\alpha$ pinene, which reduced early root growth and caused oxidative damage in the root tissue of several target species [27]. Evidence of allelopathic effects in strawberry guava leaves [24,28] points to likely inhibitory effects on native species in invaded plant communities.

Practical, cost-effective solutions to remove and control the spread of strawberry guava are not available. In Mauritius, the mechanical control of strawberry guava has a positive effect on the native flora, but due to high operational costs, only $\sim 1 \%$ of native forest remnants have received this treatment [18]. Alternatives to mechanical control include biological control agents, specifically the release of natural enemies, such as Tectococcus oyatus, and Eurytoma sp. [29]. Although T. oyatus and Eurytoma sp. have high specificity for strawberry guava, native species in the Myrtaceae family may also be impacted by the non-native biocontrol agents. These risks are especially critical in small, isolated ecosystems such as Mauritius, where only $~ 5 \%$ of native forest remains [30]. One potential but untested mitigation strategy is the addition of biochar, which can be produced from various biomass sources at low cost and does not carry the risks of biocontrol or herbicide use. Biochar-or charcoal used as soil amendment—has been widely hailed for its potential to enhance productivity and sequester carbon [31], with a recent focus on its capacity to sorb soil contaminants [32]. Research on biochar mitigation of allelopathy, however, has been limited to laboratory and greenhouse trials [24,33-35]. Long-term field studies on allelopathic interactions are scarce $[36,37]$ and none have examined the capacity of biochar to increase native tree growth in forest areas invaded by allelopathic species.

Here, we report the results of a 30-month experiment on the effects of biochar addition on native tree growth and survivorship in strawberry guava-invaded forests of Mauritius. Physical removal of aboveground biomass (weeding) and biochar treatments were applied to native tree species to test the following hypotheses: (i) strawberry guava inhibits growth and survivorship of native species, (ii) mechanical removal of strawberry guava increases native tree growth, and (iii) biochar reduces the inhibitory effects of strawberry guava and promotes native tree growth and survivorship.

\section{Materials and Methods}

\subsection{Study Site}

The experiment was established in January 2017 at the Pétrin site in Black River Gorges National Park in Mauritius $\left(20.4264^{\circ} \mathrm{S}, 57.4509^{\circ} \mathrm{E}\right)$ at $600 \mathrm{~m}$ altitude. The average annual 
temperature is $26{ }^{\circ} \mathrm{C}$, with a maximum monthly mean temperature of $29^{\circ} \mathrm{C}$ in December and a minimum of $16{ }^{\circ} \mathrm{C}$ in July. Soils on Mauritius are of volcanic origin and in the study area, they are primarily Oxisols, with patches of relatively unweathered lava [38]. Heath-type vegetation forms a large part of native plant communities in the region and the canopy rarely exceeds $3 \mathrm{~m}$ [39]. Annual precipitation in the region is 3500-4000 $\mathrm{mm}$ and the rainy season lasts from December to March. Strawberry guava is present throughout the study area and generally dominates native plant communities in the absence of mechanical weeding. In certain areas, it forms almost monospecific stands reaching up to $2 \mathrm{~m}$ in height and comprises more than $90 \%$ of all non-native woody stems. Weeded areas of the site have a more open structure than strawberry-guava-dominated stands.

\subsection{Experimental Design}

The field experiment was carried out using native woody plant species because their growth is strongly impacted by the presence of strawberry guava, and they are relevant test subjects for restoration projects in Mauritius. Four treatments (control without strawberry guava weeding or biochar addition, and strawberry guava weeding with 0,25 , or $50 \mathrm{t} / \mathrm{ha}$ biochar addition) were applied to $2 \mathrm{~m} \times 2 \mathrm{~m}$ plots using a randomized complete block design, with 5 replicates per treatment. Within blocks, plots were surrounded by a $1 \mathrm{~m}$ buffer zone, and blocks were separated from each other by a minimum distance of $30 \mathrm{~m}$. The aboveground parts of strawberry guava were manually removed from 15 plots (for three treatments with weeding and 0,25 , or $50 \mathrm{t} /$ ha biochar addition) by cutting the stems at the base. The stems were removed from the study site but fallen leaves and stumps of strawberry guava remained. The plots were not re-weeded for the duration of the experiment. In biochar treatment plots, coconut husk biochar was applied at rates of $25 \mathrm{t} / \mathrm{ha}$ and $50 \mathrm{t} / \mathrm{ha}$. Biochar was carefully incorporated into the upper $5 \mathrm{~cm}$ of soil, avoiding damage to root systems of native trees on site. In each plot, up to 9 seedlings of native species were planted, with a minimum distance of $50 \mathrm{~cm}$ between seedlings. Existing native trees in each plot were also included in the experiment, for a total of 10 individuals per plot. Seedlings of Pittosporum senacia Putt. (Pittosporaceae), Sideroxylon puberulum C.DC. (Sapotaceae), and Tambourissa peltata Baker (Monimiaceae) were obtained from nurseries managed by the National Parks and Conservation Service in Mauritius (Supplementary Figure S1); 2-3 seedlings of each of these species were transplanted into each plot. Volunteer plants in each plot were identified to species, and included S. puberulum, T. peltata, P. senacia, Syzygium coriaceum Bosser and J. Guého, Ochna mauritiana Lam., Turraea rigida Vent., and Erythrospermum monticolum Thouars var. monticolum; the volunteers represented 13 of 200 seedlings initially present in the experiment.

\subsection{Biochar Synthesis and Characterization}

A two-barrel nested retort pyrolysis system was used to make charcoal from coconut husks, which are readily available and typically discarded in large quantities in Mauritius. A $100 \mathrm{~L}$ drum of coconut husks was placed inside a larger $200 \mathrm{~L}$ drum. The space between the two drums was filled with dry branches and twigs to serve as fuel for the fire. A hole at the top of the $200 \mathrm{~L}$ drum allowed gases to escape in small amounts. Each batch of coconut feedstock was pyrolyzed at $\sim 400{ }^{\circ} \mathrm{C}$ for $4 \mathrm{~h}$ and the yield was $\sim 30 \%$ by volume. Biochar from three batches was homogenized before application. Biochar samples from each batch were collected for chemical characterization at the University of Toronto. Samples were analyzed for $\mathrm{pH}$ and EC (electrical conductivity), \% organic matter (OM), and total C and $\mathrm{N}$. Samples were dried at $60^{\circ} \mathrm{C}$ for $24 \mathrm{~h}$ and diluted to a 1:20 (v:v) ratio of sample to deionized water that was shaken for $1 \mathrm{~h}$, filtered, and measured for $\mathrm{pH}$ and $\mathrm{EC}$ using a glass electrode pH meter (IQ Scientific Instruments, Carlsbad, CA, USA) and a conductivity meter (Orion Star A112, Thermo Scientific, Waltham, MA, USA), respectively. OM was obtained by loss on ignition in a muffle furnace at $500{ }^{\circ} \mathrm{C}$ for $2 \mathrm{~h}$. Samples were weighed before and after combustion to determine the amount of OM that had been lost. Samples were dried at 
$105^{\circ} \mathrm{C}$ for $1 \mathrm{~h}$ and ground to $<0.5 \mathrm{~mm}$ for total $\mathrm{C}$ and $\mathrm{N}$ determination using a $\mathrm{CN}$ analyzer (628 Series, LECO Corporation, St. Joseph, MI, USA).

\subsection{Soil Collection and Analysis}

Soil samples were taken from the uppermost $10 \mathrm{~cm}$ of mineral soil (one per plot for all treatments) at the end of the experiment in July 2019. Soil samples were analyzed for $\mathrm{pH}, \mathrm{EC}, \% \mathrm{OM}$, and total $\mathrm{C}$ and $\mathrm{N}$; methods were similar to those used for biochar samples, but soil samples were measured for $\mathrm{pH}$ and EC using a 1:3 (v:v) ratio of sample to deionized water.

\subsection{Plant Measurements}

Plant survivorship, height (to the nearest $\mathrm{cm}$ ), and root collar diameter (to the nearest $\mathrm{mm}$ ) were measured at the start of the experiment in January 2017, after 6 months in July 2017, and at the end of the experiment in July 2019 (30 months following initiation). Root collar diameter (RCD to the nearest $0.1 \mathrm{~mm}$ ) was also measured for all trees. The number of strawberry guava individuals emerging or resprouting in each plot was measured after 6 and 30 months.

We estimated total aboveground plant biomass using diameter ${ }^{2} \mathrm{x}$ height as a proxy to avoid destructive sampling of trees that are protected for conservation in the study area. Allometric relationships between diameter ${ }^{2} \mathrm{x}$ height and biomass have been shown to closely approximate a linear relationship for several tropical tree species [40-42]. Relative volume growth rate (RGRvol) was calculated as:

$$
\text { RGRvol }=\left(\ln \left(\mathrm{D}_{2}{ }^{2} \mathrm{H}_{2}\right)-\ln \left(\mathrm{D}_{1}^{2} \mathrm{H}_{1}\right)\right) / \Delta \mathrm{t},
$$

where $\mathrm{D}_{1}{ }^{2} \mathrm{H}_{1}$ is the product of root collar diameter squared and height at the start of the experiment and $\mathrm{D}_{2}{ }^{2} \mathrm{H}_{2}$ is the product of root collar diameter squared and height either 6 or 30 months later, and $\Delta \mathrm{t}$ is the duration between the two measurements in months.

\subsection{Statistical Analysis}

Linear mixed effects models were fitted to the RGRvol data, and alternative models including block and replicate as random effects were compared using a minimum Akaike information criterion (AIC) approach [43]. Random effect terms were dropped when they were not significant and RGRvol responses were then examined using analysis of variance (ANOVA). Species-specific responses to treatments were analyzed using a 2-way ANOVA after excluding O. mauritiana, T. rigida, and E. monticolum from the dataset due to missing replicates in treatment groups. Seedling survivorship was analyzed using generalized linear mixed models with a binomial family, and block and replicate were treated as random effects. If random effect terms were not significant, survivorship was analyzed using a 2-way generalized linear model. Treatment differences for soil and biochar properties $(\mathrm{pH}$, $\mathrm{CEC}, \% \mathrm{OM}$, total $\mathrm{C}$ and $\mathrm{N}$ ) were analyzed using one-way ANOVA. Post-hoc Tukey honest significant difference (HSD) tests were used following ANOVA analyses to test pairwise treatment differences (with $p<0.05$ considered significant) for RGRvol, survivorship, and soil and biochar properties. The Shannon diversity index $\mathrm{H}^{\prime}$ was calculated for each plot using all the trees in each plot, including strawberry guava; treatment effects were analyzed using a one-way ANOVA. Treatment differences for strawberry guava density were analyzed using a one-way ANOVA. Post-hoc Scheffe tests were used to find pairwise treatment differences (with $p<0.05$ considered significant) for Shannon diversity and strawberry guava density.

We used structural equation modelling (SEM) with the R package piecewiseSEM [44] to examine drivers of native tree seedling growth and survivorship, strawberry guava density, and tree diversity. We made an a priori model for the hypothesized pathways between treatment type and response variables for native tree performance and strawberry guava density (Supplementary Figure S2). The relationships between treatment type (biochar and strawberry guava removal) and response variables (native tree growth, native seedling 
survivorship, strawberry guava density, and Shannon index) and the relationships among response variables were modelled using linear models. The best-fitting model with the lowest AIC value was obtained by removing nonsignificant pathways from poor-fitting models. Tests of directed separation were used to determine which hypothesized pathways were significant, and whether non-hypothesized significant pathways ought to be added to the model. The model was accepted if Fisher's $C$ statistic had an associated $p$-value $>0.05$ [44]. The proportional weight of each path was determined using standardized path coefficients [45]. Conditional pseudo- ${ }^{2}$ values were generated for each pathway in the model. Data analysis was conducted in $\mathrm{R}$ (version 1.1.463) specifically making use of the $\operatorname{lm}(), \operatorname{lmer}(), \operatorname{glm}()$, glmer(), and psem() functions for the main analyses.

\section{Results}

\subsection{Soil and Biochar Properties}

Soil $\mathrm{pH}$ and EC of the no-biochar treatments were significantly lower than the biochar treatments $(p<0.001)$. Biochar additions increased the organic matter content of the soil compared to no-biochar treatments, but not significantly $(p>0.05)$. Percent $\mathrm{C}$ was at similar levels across soil treatments. Biochar addition at $25 \mathrm{t} /$ ha significantly decreased soil nitrogen compared to the non-weeded control $(p<0.05)$. The coconut biochar used in the experiment had a higher $\mathrm{pH}, \mathrm{EC}, \% \mathrm{OM}, \% \mathrm{C}$, and $\% \mathrm{~N}$ compared to any soil treatment (Table 1).

Table 1. Properties of soil samples and biochar used in the experiment. Values were based on 3 samples for biochar and 5 samples for each soil treatment (one per plot replicate). Mean values are listed as $\pm 1 \mathrm{SE}$; soil treatment differences significant at $p<0.05$ (Tukey HSD post hoc tests) are indicated by different letters.

\begin{tabular}{cccccc}
\hline & & \multicolumn{4}{c}{ Treatment } \\
\cline { 3 - 6 } Attribute & Biochar (BC) & Non-Weeded & $\begin{array}{c}\text { Weeded } \\
+ \text { BC0 }\end{array}$ & $\begin{array}{c}\text { Weeded } \\
+ \text { BC25 }\end{array}$ & $\begin{array}{c}\text { Weeded } \\
+ \text { BC50 }\end{array}$ \\
\hline $\mathrm{pH}$ & $8.33 \pm 0.08$ & $6.04 \pm 0.17^{\mathrm{b}}$ & $4.75 \pm 0.08^{\mathrm{c}}$ & $6.8 \pm 0.22^{\mathrm{a}}$ & $7.04 \pm 0.08^{\mathrm{a}}$ \\
$\mathrm{EC}(\mu \mathrm{S} / \mathrm{cm})$ & $1194 \pm 110$ & $118 \pm 22.1^{\mathrm{a}}$ & $80.6 \pm 6.86^{\mathrm{a}}$ & $214 \pm 27.4^{\mathrm{b}}$ & $249 \pm 12.1^{\mathrm{b}}$ \\
OM $(\%)$ & $87 \pm 1.52$ & $20.6 \pm 4.1^{\mathrm{a}}$ & $25.6 \pm 4.23^{\mathrm{a}}$ & $40.6 \pm 8.43^{\mathrm{a}}$ & $35.7 \pm 1.37^{\mathrm{a}}$ \\
Carbon $(\%)$ & $60.5 \pm 0.79$ & $9.53 \pm 0.34^{\mathrm{a}}$ & $7.93 \pm 0.89^{\mathrm{a}}$ & $8.35 \pm 0.53^{\mathrm{a}}$ & $10.3 \pm 1.78^{\mathrm{a}}$ \\
Nitrogen $(\%)$ & $0.71 \pm 0.01$ & $0.46 \pm 0.01^{\mathrm{a}}$ & $0.40 \pm 0.01^{\mathrm{ab}}$ & $0.32 \pm 0.01^{\mathrm{b}}$ & $0.38 \pm 0.05^{\mathrm{ab}}$ \\
\hline
\end{tabular}

\subsection{Native Tree Growth and Survivorship}

Strawberry guava removal increased RGRvol relative to the control, but not significantly (Tukey HSD test: $p>0.05$ ) (Figure 1). Biochar addition significantly increased RGRvol ( $p<0.001)$ after 6 and 30 months, with much larger differences in comparison to the control. On average, biochar addition resulted in increases in RGRvol of $205 \%$ and $103 \%$ after 6 and 30 months, respectively.

Biochar addition had the most pronounced effects on $S$. coriaceum, T. peltata, and $S$. puberulum, with a threefold increase in RGRvol after 6 months $(p<0.05)$ (Figure 2a). The effects of biochar on P. senacia were also notable, with a $90 \%$ increase in RGRvol. After 30 months, RGRvol was still enhanced by biochar, but the effects were not significant for S. coriaceum and T. peltata (Figure $2 \mathrm{~b}$ ). On average, biochar addition increased RGRvol by $104 \%$ in comparison to controls, after 30 months. Species-specific responses to weeding were not significant and there were no significant differences between the low and high doses of biochar addition. 


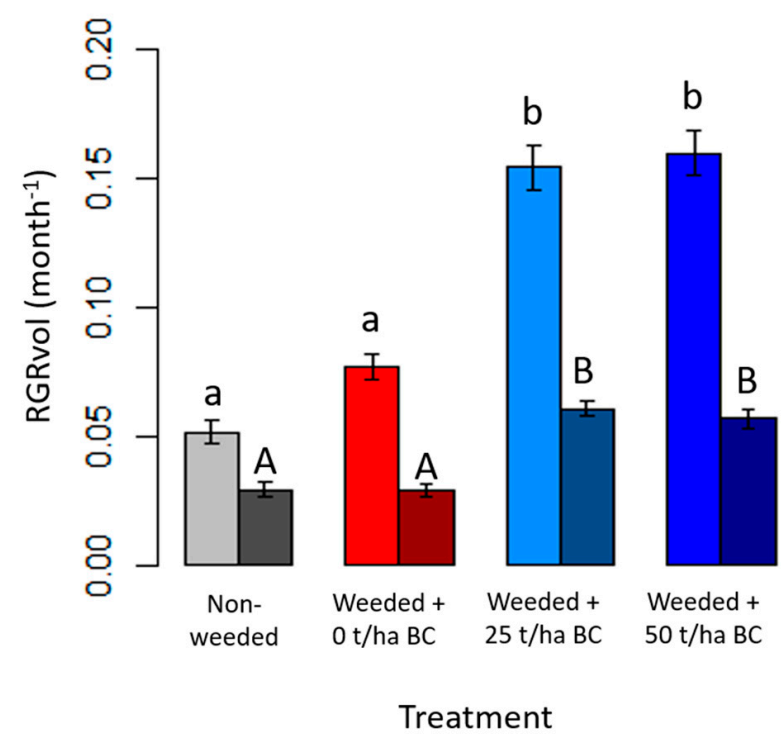

Figure 1. Relative growth rate (RGRvol) in all native seedlings and trees examined after 6 months (lighter colors) and 30 (darker colors) months. Weeding (strawberry guava removal) and biochar treatments at rates of 0,25 , and $50 \mathrm{t} / \mathrm{ha}$ are compared to the control (no weeding). Means are plotted as $\pm 1 \mathrm{SE}$; differences significant at $p<0.05$ (Tukey HSD post hoc tests) are indicated by different letters (lowercase for 6-month RGRvol and uppercase for 30-month RGRvol).

(a)

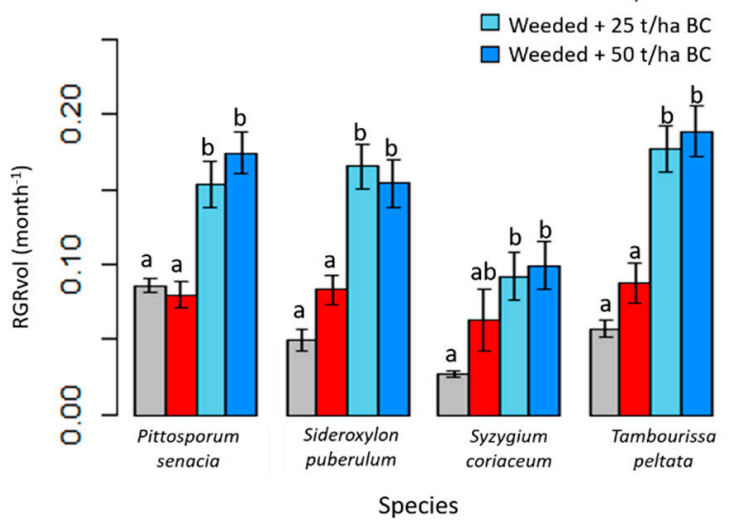

(b)

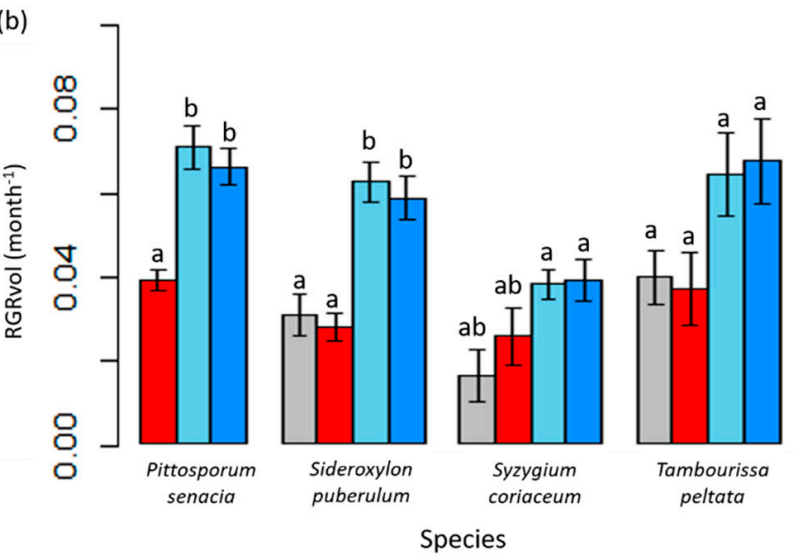

Figure 2. Relative growth rate (RGRvol) by treatment of P. senacia, S. puberulum, S. coriaceum, and T. peltata after 6 months (a) and 30 months (b). Weeding (strawberry guava removal) and biochar treatments at rates of 0,25 , and $50 \mathrm{t} / \mathrm{ha}$ are compared to the non-weeded control. Means are plotted as $\pm 1 \mathrm{SE}$; differences significant at $p<0.05$ (Tukey HSD post hoc tests) are indicated by different letters. 
Biochar addition significantly increased the survivorship of planted native seedlings, particularly P. senacia and S. puberulum seedlings, after 30 months $(p<0.05)$ (Figure 3). More than $70 \%$ of $P$. senacia and S. puberulum seedlings survived under biochar treatments, in comparison to $0 \%$ and $10 \%$ survivorship in control plots, respectively. Weeding also had significant positive effects on the survivorship of $S$. puberulum seedlings, with a sixfold increase compared to the control $(p<0.01)$. The survivorship of T. peltata did not differ among treatments.
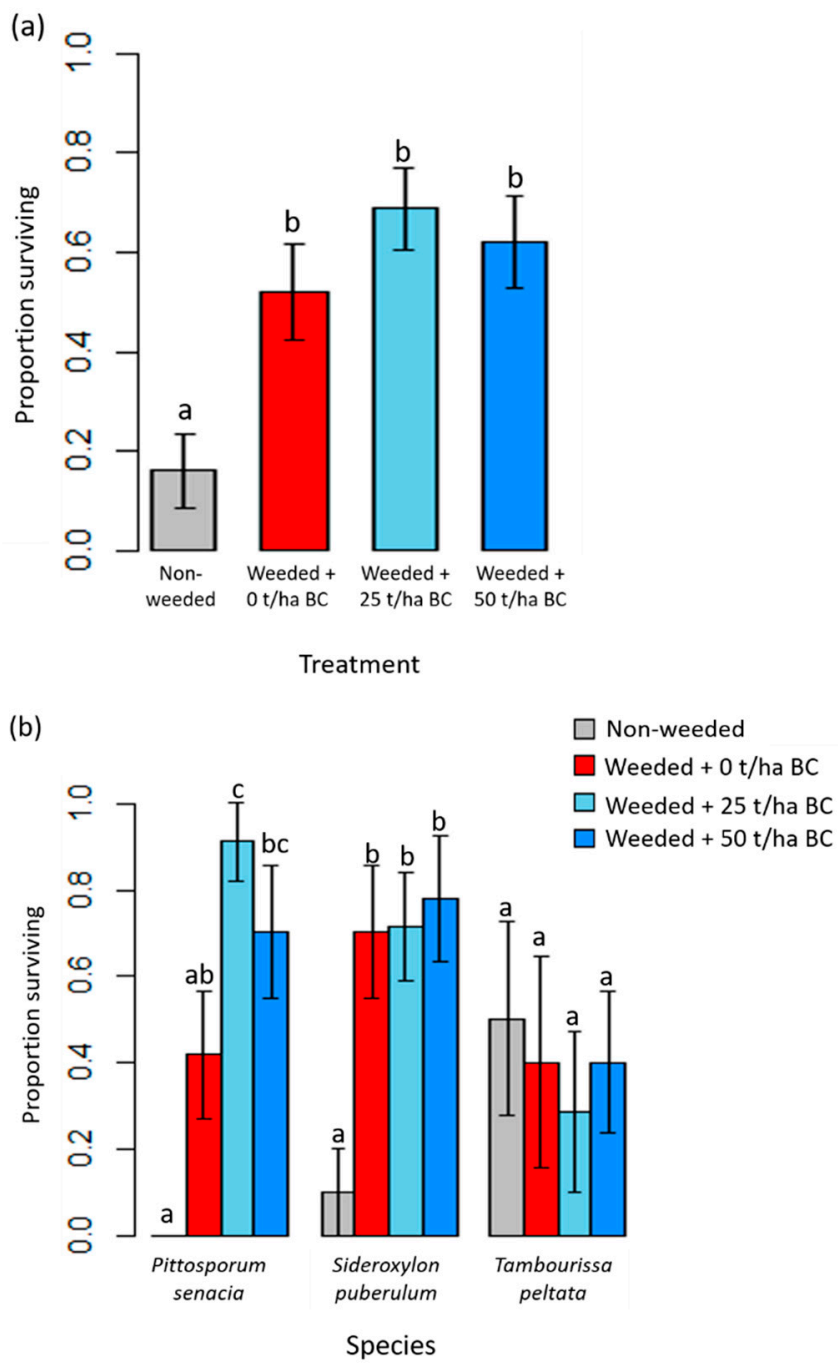

Figure 3. Proportion of native seedling survivorship after 30 months by treatment: (a) pooled data; (b) by species for P. senacia, S. puberulum, and T. peltata. Weeding (strawberry guava removal) and biochar treatments at rates of 0,25 , and $50 \mathrm{t} / \mathrm{ha}$ are compared to the non-weeded control. Means are plotted as $\pm 1 \mathrm{SE}$; differences significant at $p<0.05$ (Tukey HSD post hoc tests) are indicated by different letters.

\subsection{Strawberry Guava Density}

Strawberry guava regeneration (from resprouting) was significantly reduced in response to weeding and biochar addition after 6 and 30 months $(p<0.01)$ (Figure 4$)$. Strawberry guava density was significantly higher for the control compared with all other treatments, but strawberry guava density between biochar addition treatments were not significantly different $(p>0.05)$. Strawberry guava density in the no-biochar weeded treatment was $\sim 50 \%$ lower than the control after 30 months. Biochar addition dramatically reduced strawberry guava density, which was four times lower than the control treatment. 


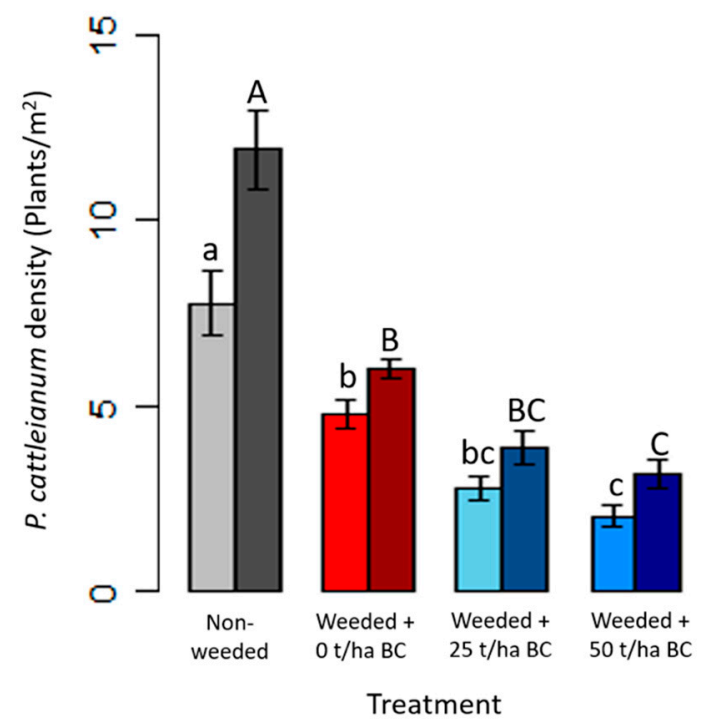

Figure 4. Density of strawberry guava individuals by treatment after 6 months (lighter colors) and 30 months (darker colors). Weeding (strawberry guava removal) and biochar treatments at rates of 0 , 25 , and $50 \mathrm{t} / \mathrm{ha}$ are compared to the non-weeded control. Means are plotted as $\pm 1 \mathrm{SE}$; differences significant at $p<0.05$ (Scheffe post hoc tests) are indicated by different letters (lowercase for 6-month period and uppercase for 30-month period).

\subsection{Diversity}

Weeding increased the Shannon diversity index for all trees detected within plots after 30 months compared to the control treatment, but not significantly $(p>0.05)$ (Figure 5). Biochar addition significantly increased Shannon diversity $(p<0.01)$ after 30 months, with larger differences in comparison to the control. On average, Shannon diversity doubled with biochar addition compared to the control treatment, but it was not significantly different between the two biochar addition dosages.

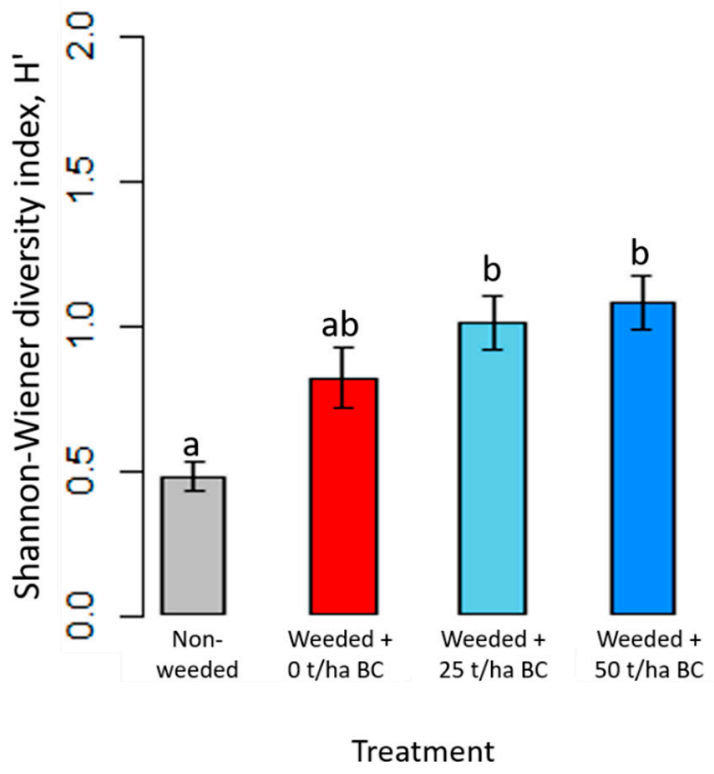

Figure 5. Shannon diversity by treatment after 30 months. Weeding (strawberry guava removal) and biochar treatments at rates of 0,25 , and $50 \mathrm{t} /$ ha are compared to the non-weeded control. Means are plotted as $\pm 1 \mathrm{SE}$; differences significant at $p<0.05$ (Scheffe post hoc tests) are indicated by different letters. 


\subsection{Structural Equation Model}

Our structural equation model (SEM) showed that strawberry guava density decreased native tree growth $(p<0.01)$, while biochar additions increased growth $(p<0.01)$ (Figure 6). Strawberry guava density was significantly reduced by strawberry guava weeding $(p<0.001)$ and biochar additions $(p=0.002)$, with stronger effects of weeding compared to biochar. Native seedling survivorship increased significantly in response to early tree growth $(p<0.01)$. Native tree diversity increased with survivorship $(p<0.001)$ and was negatively affected by strawberry guava density $(p<0.01)$.

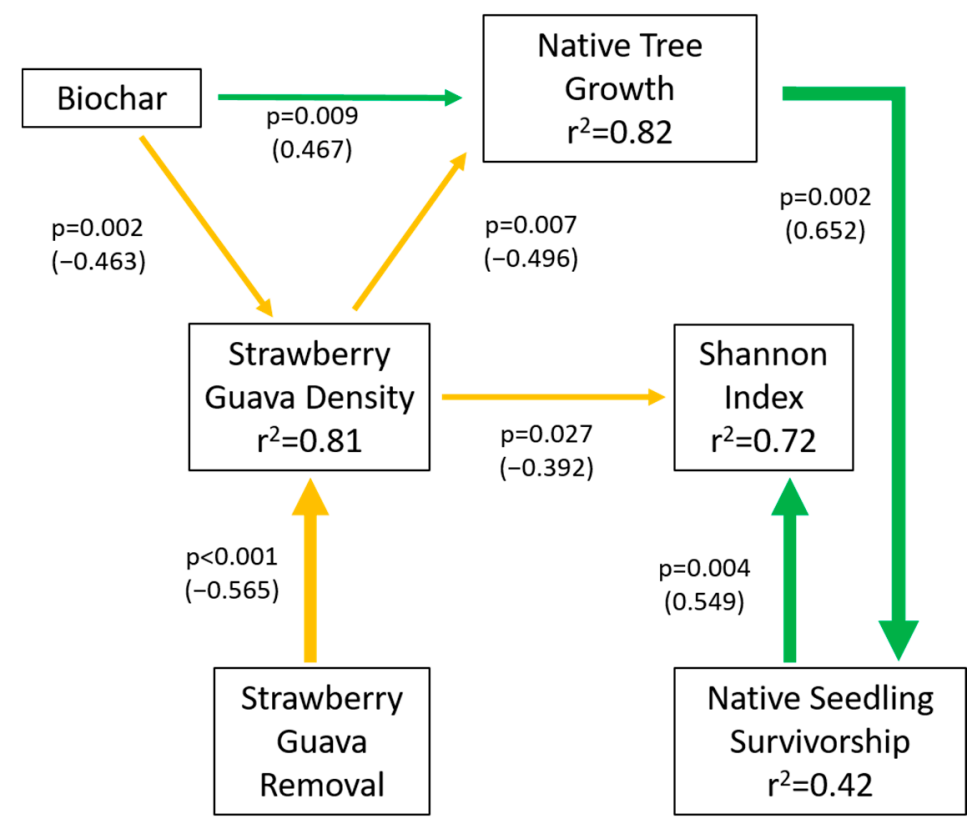

Figure 6. Structural equation model illustrating drivers of native tree growth, native seedling survivorship, strawberry guava density, and tree diversity in the experiment. Arrow thickness is proportional to path coefficients. Values listed by arrows are standardized path coefficients with $p$-values. An $\mathrm{r}^{2}$ value is shown in the box of each response variable.

\section{Discussion}

Our results support the hypotheses that (i) strawberry guava suppresses the survivorship of native trees and that (iii) persistent negative effects of allelochemicals on native tree growth and survivorship can be largely overcome by biochar applications to the upper soil horizons. We did not find evidence to support our hypothesis that (ii) strawberry guava weeding increases native tree growth; however, removal of aboveground parts had a positive effect on native tree survivorship. Moreover, notable biochar effects were observed for all native tree species examined, and overall tree diversity in plots was strongly enhanced by biochar treatments. Our structural equation model (SEM) indicates that native tree growth was greatly reduced in the presence of high strawberry guava density and increased significantly in response to biochar additions. Direct effects of the predictor variables, strawberry guava density and biochar dosage, explained $82 \%$ of the variation in native tree growth (Figure 6). Our most unexpected result was that strawberry guava removal alone did not significantly increase native tree growth. However, in non-weeded plots, strawberry guava strongly suppressed the survivorship of native seedlings; there were no P. senacia survivors in the control plots after 30 months (Figure 3). This result is consistent with prior studies that have found that native seedling survival decreased in the presence of invasive species such as Ligustrum sinense [46] and Lonicera maackii [47]. Native tree species in Hawaii's lowland wet forests are severely suppressed by high densities of strawberry guava dominating invaded forest stands $[9,19]$. Our findings are also consistent with prior studies that have found the removal of strawberry guava to be beneficial for 
native trees. In lowland wet forests of Mauritius, the reproductive output [18] and regeneration of native tree species have been found to be greater in weeded areas, with effects including resprouting of endemic species that were presumed extinct in Mauritius [48].

The positive survivorship responses of native seedlings to $P$. cattleianum weeding indicate that strawberry guava has negative effects on the native plant community, likely due to a combination of both resource competition and allelopathy [24,47,49]. Light limitation under the dense stands of invasive plants has been found to be the most important factor affecting the performance of native species [46,50]. Increased light availability in our weeded plots was likely an important mechanism for higher survivorship of native seedlings because strawberry guava grows in dense thickets such that very little light reaches the forest floor. Although strawberry guava density was significantly higher in the control plots than the no-biochar weeded plots (Figure 4), native tree growth was not significantly different between the two treatments (Figure 1), which suggests that resource competition was not the only mechanism affecting tree growth. Allelochemicals released by strawberry guava $[24,51]$ likely suppressed native tree growth in the no-biochar weeded plots, in addition to the effects from competition for resources such as light, nutrients, and water $[46,47]$. Strawberry guava releases several allelopathic compounds, including $\beta$-caryophyllene, $\alpha$-pinene, and phenolics [10,11], all of which have been shown to inhibit plant growth $[37,38,52]$. Copious fruiting of strawberry guava [8] could substantially increase the inhibitory effects of the allelochemicals because the fruits contain high levels of phenolics and other allelopathic compounds [53]. Similarly, Siemens and Blossey [54] found that higher light availability increased the survivorship but not growth of Eupatorium perfoliatum in response to the removal of the invasive plant, Reynoutria $\mathrm{x}$ bohemica (formerly Fallopia $\mathrm{x}$ bohemica). Similar to the present study, they found that activated carbon had greater positive effects on E. perfoliatum growth than nutrient additions, consistent with activated carbon acting to alleviate the allelopathic effects.

Biochar strongly increased the growth of all the native species examined, and effects of biochar additions on tree growth were much greater than the effects of strawberry guava weeding alone (Figures 1 and 2). The primary mechanism for this effect is almost certainly the sorption of allelochemicals, which was previously demonstrated in laboratory experiments [24]. Biochar has specifically been shown to sorb some of the major allelochemicals released by strawberry guava, such as phenolic compounds and $\alpha$-pinene $[55,56]$, and the significant positive responses of native tree growth to biochar addition are consistent with the sorption of these allelochemicals in situ. Biochar additions may also positively affect tree growth by other mechanisms, including increased nutrient availability $[57,58]$, increased soil pH, and increased soil water retention [59]. The coconut biochar used in this experiment had a high $\mathrm{pH}$ and significantly increased the $\mathrm{pH}$ of soil treatments amended with biochar (Table 1). Coconut biochar is very basic $[60,61]$ and can increase the availability of nutrients by increasing the $\mathrm{pH}$ of acidic tropical soils. $\mathrm{P}$ availability is strongly influenced by soil $\mathrm{pH}$ and is bound up in insoluble iron and aluminum phosphates in acidic soils [59], but basic biochars can increase $\mathrm{P}$ availability. The solubility of $\mathrm{N}, \mathrm{Mg}$, and $\mathrm{Ca}$ in acidic soils is also commonly enhanced in the presence of biochars [62,63]. Higher EC in biochar-amended soils (Table 1) indicates the presence of mineral ions [64], which likely contributed to increased tree growth.

Biochar additions resulted in particularly significant positive responses on the growth and survivorship of P. senacia and S. puberulum after 30 months. Several studies have found strong species-specific responses to biochar addition $[65,66]$, including negative responses in some cases [67]. Some species have a superior capacity to exploit resources and may benefit more from enrichment of specific nutrients [68]. For example, $\mathrm{P}$ addition favored the growth of a dominant pioneer tree, Rollinia exsucca, over coexisting species [69]. Species that are more sensitive to allelopathic effects may also benefit more from sorption of allelochemicals by biochar. Differential responses of native tree growth and survivorship to biochar may have long-term effects on species richness and diversity. According to our structural equation model, reduced strawberry guava density also contributed significantly 
to tree diversity (Figure 6). We found that tree diversity was lowest in the control plots but increased substantially after the removal of strawberry guava and biochar addition (Figure 5). Prior studies indicate that biochar addition can have strong effects on plant community composition $[70,71]$ and has been found to promote species richness in a reforested site, with potential impacts on overall biodiversity [65]. The present study is the first to demonstrate positive diversity effects of biochar in tropical forest restoration.

Strawberry guava density was greatly reduced even 30 months after weeding and biochar addition (Figure 4). The structural equation model showed that direct effects of strawberry guava removal and biochar dosage explained $81 \%$ of the variation in strawberry guava density (Figure 6). Lower strawberry guava density in weeded plots suggests that native trees were able to resist re-invasion by strawberry guava to some extent. The survivorship of native seedlings was higher in weeded plots (Figure 3a), and it seems likely that strawberry guava was suppressed by a higher density of native species in these plots compared to the control. Prior studies have found that some native species have great potential to suppress the growth of invasive species in re-vegetation field experiments [72,73]. Replacement of invasive plants with strong native competitors can thus increase the success of native forest restoration projects.

Invasive species commonly have a superior ability to acquire nutrients, and nutrient additions, particularly of $\mathrm{N}$, can often be more beneficial to invasive species than to native species $[68,74,75]$. In contrast, low $\mathrm{N}$ levels have been found to reduce competitive pressure from invasive species and even promote dominance of native species [76-78]. Strawberry guava performance has been also found to be strongly affected by soil N levels; leaf $\mathrm{N}$ uptake and flower production increased rapidly after nitrogen fertilization [79]. Although biochar can increase nutrient availability, in many cases, it has been found to reduce available soil $\mathrm{N}$ [80]. In the present study, it seems likely that lower $\mathrm{N}$ levels in biochar-amended soils (Table 1 ) helped suppress the regeneration of strawberry guava. Adams et al. [81] reported strong negative effects of biochar addition on the invasive species Lespedeza cuneata when $\mathrm{N}$ was limiting, but positive effects on the native species Andropogon gerardii [81]. Sorption of allelochemicals that may be beneficial to strawberry guava is another potential mechanism for reduced strawberry guava regeneration in response to biochar treatments. Callaway and Aschehoug [1] found that activated carbon reduced the growth of the invasive Eurasian plant Centaurea diffusa in the presence of native North American competitors after controlling for spatial root niche partitioning, suggesting that its competitive advantage is at least partially mediated by allelopathic effects and that sorption of allelochemicals can allow native species to reclaim dominance of the native plant communities. $\beta$-caryophyllene, the main allelochemical found in strawberry guava leaves, is also produced by maize plants and has been found to protect maize roots and leaves from herbivore damage by attracting natural enemies of the herbivores [82,83]. Sorption of such allelochemicals by biochar might thus make strawberry guava more vulnerable to attacks by pathogens and herbivores.

Biochar addition at rates of $25 \mathrm{t} / \mathrm{ha}$ and $50 \mathrm{t} /$ ha resulted in similar increases in tree growth (Figures 1 and 2). Prior studies suggest that plant growth responses to biochar application peaked at moderate doses of $\sim 20-30 \mathrm{t} / \mathrm{ha}[84,85]$, though a higher optimum (of 50-60 t/ha) has been found in a recent study examining growth responses to natural post-fire pyrogenic carbon deposition [86]. In the present study, we did not observe large differences in the growth responses of native species between the 25 and $50 \mathrm{t} /$ ha treatments. A dose of $25 \mathrm{t} /$ ha may thus be sufficient for an optimal increase in tree growth through biochar treatment and is more practical for application to larger areas of forest soils. In the present study, strawberry guava was only removed once, but we recommend repeated weeding to augment the positive effects of biochar on native tree growth. Repeated biochar applications may also be beneficial. Our results suggest that biochar application can reduce the frequency of weeding by suppressing the regeneration of strawberry guava. Further research is needed to investigate the effects of biochar on native microbial communities and fauna prior to large-scale applications to forest soils. 


\section{Conclusions}

We conclude that biochar has significant positive effects on native tree growth and survivorship in native forest communities invaded by strawberry guava. Our results are consistent with biochar reducing allelopathic effects and thus altering the competitive balance of native and invasive species, thereby favoring the former. Mechanical removal of invasive species in Mauritius is labor-intensive and costly, but biochar addition can enhance the beneficial effects on native species and reduce the encroachment of strawberry guava after initial weeding. Biochar can be produced from readily available plant biomass waste at relatively low cost; in Mauritius, weeded strawberry guava stems are an obvious feedstock option, although further research is needed to test the effects of strawberry guava biochar. Sorption or immobilization of allelochemicals seem to be particularly important for reducing invasions of allelopathic introduced species into native plant communities. However, the capacity of biochar to mitigate the inhibitory effects of certain invasive species may be less pronounced when larger allelopathic compounds are involved. For example, biochar was only able to marginally alleviate the allelopathic effects of Ailanthus altissima, possibly due to steric effects that reduce sorption of large polyaromatic molecules [34]. Biochar appears to be a viable tool for combatting several tropical allelopathic invasive species, but a combination of laboratory and field studies is necessary to examine the properties and dosages of biochar that will optimize sorption of allelochemicals and native tree growth in invaded ecosystems. Imperata cylindrica, Lantana camara, and Chromolaena odorata are strongly allelopathic invasive species that have particularly serious impacts on tropical biodiversity - biochar trials targeting these species are thus a priority for further work in this area. Future research should also examine biochar effects on soil microbial communities and plant mineral nutrition in the context of allelopathic invasive species, since these effects, in addition to sorption of allelochemicals, are likely to be critical in determining overall impacts on native plant species.

Supplementary Materials: The following supporting information can be downloaded at: https: / / www.mdpi.com/article/10.3390/f13020277/s1, Figure S1. Photographs of study species in the experiment. Figure S2. A priori structural equation model of hypothesized pathways.

Author Contributions: Conceptualization, L.S. and S.C.T.; methodology, formal analysis, and investigation, L.S.; resources, S.C.T.; data curation, L.S.; writing-original draft preparation, L.S.; writing—review and editing, S.C.T.; visualization, L.S.; supervision and project administration, S.C.T.; funding acquisition, L.S. and S.C.T. All authors have read and agreed to the published version of the manuscript.

Funding: This research was funded by grants from the Canadian Natural Sciences and Engineering Research Council and by the crowd-funding source Experiment.com (accessed on 20 December 2021).

Data Availability Statement: All data can be provided upon request to the corresponding author.

Acknowledgments: We thank the National Parks and Conservation Service for permission to carry out research in the Black River Gorges National Park and provision of native species seedlings. We also thank Mario Allet for assistance with species identification and comments on this work. This research was funded by the generous donors on the crowdfunding platform Experiment.com (accessed on 20 December 2021), and the Canadian Natural Sciences and Engineering Research Council.

Conflicts of Interest: The authors declare no conflict of interest.

\section{References}

1. Callaway, R.M.; Aschehoug, E.T. Invasive plants versus their new and old neighbors: A mechanism for exotic invasion. Science 2000, 290, 521-523. [CrossRef] [PubMed]

2. Cappuccino, N.; Arnason, J.T. Novel chemistry of invasive exotic plants. Biol. Lett. 2006, 2, 189-193. [CrossRef] [PubMed]

3. Van Kleunen, M.; Dawson, W.; Maurel, N. Characteristics of successful alien plants. Mol. Ecol. 2015, 24, 1954-1968. [CrossRef] [PubMed]

4. Kalisz, S.; Kivlin, S.N.; Bialic-Murphy, L. Allelopathy is pervasive in invasive plants. Biol. Invasions 2021, 23, 367-371. [CrossRef] 
5. Hagan, D.L.; Jose, S.; Lin, C.H. Allelopathic exudates of cogongrass (Imperata cylindrica): Implications for the performance of native pine savanna plant species in the Southeastern US. J. Chem. Ecol. 2013, 39, 312-322. [CrossRef]

6. Hu, G.; Zhang, Z. Allelopathic effects of Chromolaena odorata on native and non-native invasive herbs. J. Food. Agric. Environ. 2013, $11,878-882$.

7. Kato-Noguchi, H.; Kurniadie, D. Allelopathy of Lantana camara as an invasive plant. Plants 2021, 10, 1028. [CrossRef] [PubMed]

8. Huenneke, L.F.; Vitousek, P.M. Seedling and clonal recruitment of the invasive tree Psidium cattleianum: Implications for management of native Hawaiian forests. Biol. Conserv. 1990, 53, 199-211. [CrossRef]

9. Mascaro, J.; Becklund, K.K.; Hughes, R.F.; Schnitzer, S.A. Limited native plant regeneration in novel, exotic-dominated forests on Hawai'i. For. Ecol. Manag. 2008, 256, 593-606. [CrossRef]

10. Patel, S. Exotic tropical plant Psidium cattleianum: A review on prospects and threats. Rev. Environ. Sci. Biotechnol. 2012, 11, 243-248. [CrossRef]

11. Pino, J.A.; Marbot, R.; Vázquez, C. Characterization of volatiles in strawberry guava (Psidium cattleianum Sabine) Fruit. J. Agric. Food Chem. 2001, 49, 5883-5887. [CrossRef] [PubMed]

12. Wan, J.Z.; Wang, C.J. Expansion risk of invasive plants in regions of high plant diversity: A global assessment using 36 species. Ecol. Inform. 2018, 46, 8-18. [CrossRef]

13. van Kleunen, M.; Dawson, W.; Essl, F.; Pergl, J.; Winter, M.; Weber, E.; Kreft, H.; Weigelt, P.; Kartesz, J.; Nishino, M.; et al. Global exchange and accumulation of non-native plants. Nature 2015, 525, 100-103. [CrossRef]

14. Denslow, J.S. Weeds in paradise: Thoughts on the invasibility of tropical islands. Ann. Mo. Bot. Gard. 2003, 90, 119-127. [CrossRef]

15. Lorence, D.H.; Sussman, R.W. Exotic species invasion into Mauritius wet forest remnants. J. Trop. Ecol. 1986, 2, 147-162. [CrossRef]

16. Schumacher, E.; Kueffer, C.; Tobler, M.; Gmür, V.; Edwards, P.J.; Dietz, H. Influence of drought and shade on seedling growth of native and invasive trees in the Seychelles. Biotropica 2008, 40, 543-549. [CrossRef]

17. Florens, F.B.V.; Baider, C.; Seegoolam, N.B.; Zmanay, Z.; Strasberg, D. Long-term declines of native trees in an oceanic island's tropical forests invaded by alien plants. Appl. Veg. Sci. 2017, 20, 94-105. [CrossRef]

18. Monty, M.L.F.; Florens, F.B.V.; Baider, C. Invasive alien plants elicit reduced production of flowers and fruits in various native forest species on the tropical island of Mauritius (Mascarenes, Indian Ocean). Trop. Conserv. Sci. 2013, 6, 35-49. [CrossRef]

19. Zimmerman, N.; Hughes, R.F.; Cordell, S.; Hart, P.; Chang, H.K.; Perez, D.; Like, R.K.; Ostertag, R. Patterns of primary succession of native and introduced plants in lowland wet forests in eastern Hawai'i. Biotropica 2008, 40, 277-284. [CrossRef]

20. Florens, F.V.; Baider, C.; Martin, G.M.; Strasberg, D. Surviving 370 years of human impact: What remains of tree diversity and structure of the lowland wet forests of oceanic island Mauritius? Biodivers. Conserv. 2012, 21, 2139-2167. [CrossRef]

21. Myers, N.; Mittermeier, R.A.; Mittermeier, C.G.; da Fonseca, G.A.B.; Kent, J. Biodiversity hotspots for conservation priorities. Nature 2000, 403, 853-858. [CrossRef] [PubMed]

22. Baider, C.; Florens, F.V.; Baret, S.; Beaver, K.; Matatiken, D.; Strasberg, D.; Kueffer, C. Status of plant conservation in oceanic islands of the Western Indian Ocean. In Proceedings of the 4th Global Botanic Gardens Congress, Dublin, Ireland, 13-18 June 2010; Volume 2, pp. 1-7.

23. Virah-Sawmy, M.; Mauremootoo, J.; Marie, D.; Motala, S.; Sevathian, J.C. Rapid degradation of a Mauritian rainforest following 60 years of plant invasion. Oryx 2009, 43, 599. [CrossRef]

24. Sujeeun, L.; Thomas, S.C. Potential of biochar to mitigate allelopathic effects in tropical island invasive plants: Evidence from seed germination trials. Trop. Conserv. Sci. 2017, 10, 194008291769726. [CrossRef]

25. Adam, F.; Vahirua-Lechat, I.; Deslandes, E.; Menut, C. Aromatic plants of French Polynesia. V. chemical composition of essential oils of leaves of Psidium guajava L. and Psidium cattleyanum Sabine. J. Essent. Oil Res. 2011, 23, 98-101. [CrossRef]

26. Kong, C.; Hu, F.; Xu, T.; Lu, Y. Allelopathic potential and chemical constituents of volatile oil from Ageratum conyzoides. J. Chem. Ecol. 1999, 25, 2347-2356. [CrossRef]

27. Singh, H.P.; Batish, D.R.; Kaur, S.; Arora, K.; Kohli, R.K. $\alpha$-pinene inhibits growth and induces oxidative stress in roots. Ann. Bot. 2006, 98, 1261-1269. [CrossRef] [PubMed]

28. Hister, C.A.L.; Trapp, K.C.; Tedesco, S.B. Potencial alelopático e antiproliferativo de extratos aquosos das folhas de Psidium cattleianum Sabine sobre Lactuca sativa L. Braz. J. Biol. Sci. 2016, 14, 131.

29. Wikler, C.; Smith, C.W.; Pedrosa-Macedo, J.H. The stem-gall wasp Eurytoma sp. (Hymenoptera: Eurytomidae): A potential biological control agent against Psidium cattleianum. In Proceedings of the IX International Symposium on Biological Control of Weeds, Stellenbosch, South Africa, 19-26 January 1996; pp. 219-221.

30. Safford, R.J. A survey of the occurrence of native vegetation remnants on Mauritius in 1993. Biol. Conserv. 1997, 80, 181-188. [CrossRef]

31. Lehmann, J.; Joseph, S. Biochar for Environmental Management: Science, Technology and Implementation, 2nd ed.; Routledge: London, UK, 2015; ISBN 9780367779184.

32. Ahmad, M.; Rajapaksha, A.U.; Lim, J.E.; Zhang, M.; Bolan, N.; Mohan, D.; Vithanage, M.; Lee, S.S.; Ok, Y.S. Biochar as a sorbent for contaminant management in soil and water: A review. Chemosphere 2014, 99, 19-33. [CrossRef] [PubMed]

33. Alshahrani, T.S.; Suansa, N.I. Application of biochar to alleviate effects of allelopathic chemicals on seed germination and seedling growth. BioResources 2020, 15, 382-400.

34. Bieser, J.M.; Al-Zayat, M.; Murtada, J.; Thomas, S.C. Biochar mitigation of allelopathic effects in three invasive plants: Evidence from seed germination trials. Can. J. Soil Sci. 2022, in press. [CrossRef] 
35. Shen, Y.; Tang, H.; Wu, W.; Shang, H.; Zhang, D.; Zhan, X.; Xing, B. Role of nano-biochar in attenuating the allelopathic effect from Imperata cylindrica on rice seedlings. Environ. Sci. Nano 2020, 7, 116-126. [CrossRef]

36. Chu, C.; Mortimer, P.E.; Wang, H.; Wang, Y.; Liu, X.; Yu, S. Allelopathic effects of Eucalyptus on native and introduced tree species For. Ecol. Manag. 2014, 323, 79-84. [CrossRef]

37. Del Fabbro, C.; Güsewell, S.; Prati, D. Allelopathic effects of three plant invaders on germination of native species: A field study. Biol. Invasions 2014, 16, 1035-1042. [CrossRef]

38. Panagos, P.; Jones, A.; Bosco, C.; Senthil Kumar, P.S. European digital archive on soil maps (EuDASM): Preserving important soil data for public free access. Int. J. Digit. Earth 2011, 4, 434-443. [CrossRef]

39. Hansen, D.M.; Olesen, J.M.; Jones, C.G. Trees, birds and bees in Mauritius: Exploitative competition between introduced honeybees and endemic nectarivorous birds? J. Biogeogr. 2002, 29, 721-734. [CrossRef]

40. Kohyama, T.; Hotta, M. Significance of allometry in tropical saplings. Funct. Ecol. 1990, 4, 515-521. [CrossRef]

41. Mokria, M.; Mekuria, W.; Gebrekirstos, A.; Aynekulu, E.; Belay, B.; Gashaw, T.; Bräuning, A. Mixed-species allometric equations and estimation of aboveground biomass and carbon stocks in restoring degraded landscape in northern Ethiopia. Environ. Res. Lett. 2018, 13, 024022. [CrossRef]

42. Zeng, H.Q.; Liu, Q.J.; Feng, Z.W.; Ma, Z.Q. Biomass equations for four shrub species in subtropical China. J. For. Res. 2010, 15, 83-90. [CrossRef]

43. Bates, D.; Mächler, M.; Bolker, B.; Walker, S. lme4: Linear Mixed-Effects Models Using Eigen and S4, R Package Version, 1(7). Available online: https:/ / cran.r-project.org/web/packages/lme4/lme4.pdf (accessed on 20 October 2021).

44. Lefchek, J.S. piecewiseSEM: Piecewise structural equation modeling in R for ecology, evolution, and systematics. Methods Ecol. Evol. 2016, 7, 573-579. [CrossRef]

45. Grace, J.B.; Bollen, K.A. Interpreting the results from multiple regression and structural equation models. Bull. Ecol. Soc. Am. 2005, 86, 283-295. [CrossRef]

46. Greene, B.T.; Blossey, B. Lost in the weeds: Ligustrum sinense reduces native plant growth and survival. Biol. Invasions 2012, 14, 139-150. [CrossRef]

47. Gould, A.M.A.; Gorchov, D.L. Effects of the exotic invasive shrub Lonicera maackii on the survival and fecundity of three species of native annuals. Am. Midl. Nat. 2000, 144, 36-50. [CrossRef]

48. Baider, C.; Florens, F.B.V. Control of invasive alien weeds averts imminent plant extinction. Biol. Invasions 2011, 13, 2641-2646. [CrossRef]

49. Belote, R.T.; Weltzin, J.F. Interactions between two co-dominant, invasive plants in the understory of a temperate deciduous forest. Biol. Invasions 2006, 8, 1629-1641. [CrossRef]

50. Gorchov, D.L.; Trisel, D.E. Competitive effects of the invasive shrub, Lonicera maackii (Rupr.) Herder (Caprifoliaceae), on the growth and survival of native tree seedlings. Plant Ecol. 2003, 166, 13-24. [CrossRef]

51. Dacoreggio, M.V.; Moroni, L.S.; Kempka, A.P. Antioxidant, antimicrobial and allelopathic activities and surface disinfection of the extract of Psidium cattleianum sabine leaves. Biocatal. Agric. Biotechnol. 2019, 21, 101295. [CrossRef]

52. Golisz, A.; Lata, B.; Gawronski, S.W.; Fujii, Y. Specific and total activities of the allelochemicals identified in buckwheat. Weed Biol. Manag. 2007, 7, 164-171. [CrossRef]

53. Medina, A.L.; Haas, L.I.R.; Chaves, F.C.; Salvador, M.; Zambiazi, R.C.; da Silva, W.P.; Nora, L.; Rombaldi, C.V. Araçá (Psidium cattleianum Sabine) fruit extracts with antioxidant and antimicrobial activities and antiproliferative effect on human cancer cells. Food Chem. 2011, 128, 916-922. [CrossRef]

54. Siemens, T.J.; Blossey, B. An evaluation of mechanisms preventing growth and survival of two native species in invasive Bohemian knotweed (Fallopia $\times$ bohemica, Polygonaceae). Am. J. Bot. 2007, 94, 776-783. [CrossRef]

55. Hale, S.E.; Endo, S.; Arp, H.P.H.; Zimmerman, A.R.; Cornelissen, G. Sorption of the monoterpenes $\alpha$-pinene and limonene to carbonaceous geosorbents including biochar. Chemosphere 2015, 119, 881-888. [CrossRef] [PubMed]

56. Wardle, D.A.; Zackrisson, O.; Nilsson, M.C. The charcoal effect in boreal forests: Mechanisms and ecological consequences. Oecologia 1998, 115, 419-426. [CrossRef]

57. Pluchon, N.; Gundale, M.J.; Nilsson, M.-C.; Kardol, P.; Wardle, D.A. Stimulation of boreal tree seedling growth by wood-derived charcoal: Effects of charcoal properties, seedling species and soil fertility. Funct. Ecol. 2014, 28, 766-775. [CrossRef]

58. Thomas, S.C.; Gale, N. Biochar and forest restoration: A review and meta-analysis of tree growth responses. New For. 2015, 46, 931-946. [CrossRef]

59. Atkinson, C.J.; Fitzgerald, J.D.; Hipps, N.A. Potential mechanisms for achieving agricultural benefits from biochar application to temperate soils: A review. Plant Soil 2010, 337, 1-18. [CrossRef]

60. Lee, Y.; Park, J.; Ryu, C.; Gang, K.S.; Yang, W.; Park, Y.-K.; Jung, J.; Hyun, S. Comparison of biochar properties from biomass residues produced by slow pyrolysis at $500{ }^{\circ} \mathrm{C}$. Bioresour. Technol. 2013, 148, 196-201. [CrossRef] [PubMed]

61. Suman, S.; Gautam, S. Pyrolysis of coconut husk biomass: Analysis of its biochar properties. Energy Sources Part Recovery Util. Environ. Eff. 2017, 39, 761-767. [CrossRef]

62. Biederman, L.A.; Harpole, W.S. Biochar and its effects on plant productivity and nutrient cycling: A meta-analysis. GCB Bioenergy 2013, 5, 202-214. [CrossRef]

63. Liu, X.; Zhang, A.; Ji, C.; Joseph, S.; Bian, R.; Li, L.; Pan, G.; Paz-Ferreiro, J. Biochar's effect on crop productivity and the dependence on experimental conditions-a meta-analysis of literature data. Plant Soil 2013, 373, 583-594. [CrossRef] 
64. Schulz, H.; Dunst, G.; Glaser, B. Positive effects of composted biochar on plant growth and soil fertility. Agron. Sustain. Dev. 2013, 33, 817-827. [CrossRef]

65. Drake, J.A.; Carrucan, A.; Jackson, W.R.; Cavagnaro, T.R.; Patti, A.F. Biochar application during reforestation alters species present and soil chemistry. Sci. Total Environ. 2015, 514, 359-365. [CrossRef] [PubMed]

66. Gale, N.V.; Halim, M.A.; Horsburgh, M.; Thomas, S.C. Comparative responses of early-successional plants to charcoal soil amendments. Ecosphere 2017, 8, e01933. [CrossRef]

67. Spokas, K.A.; Cantrell, K.B.; Novak, J.M.; Archer, D.W.; Ippolito, J.A.; Collins, H.P.; Boateng, A.A.; Lima, I.M.; Lamb, M.C.; Lentze, R.D.; et al. Biochar: A synthesis of its agronomic impact beyond carbon sequestration. J. Environ. Qual. 2012, 41, 973-989. [CrossRef]

68. Gioria, M.; Osborne, B.A. Resource competition in plant invasions: Emerging patterns and research needs. Front. Plant Sci. 2014, 5, 501. [CrossRef]

69. Siddique, I.; Vieira, I.C.G.; Schmidt, S.; Lamb, D.; Carvalho, C.J.R.; de Figueiredo, R.O.; Blomberg, S.; Davidson, E.A. Nitrogen and phosphorus additions negatively affect tree species diversity in tropical forest regrowth trajectories. Ecology 2010, 91, 2121-2131. [CrossRef]

70. Bieser, J.M.; Thomas, S.C. Biochar and high-carbon wood ash effects on soil and vegetation in a boreal clearcut. Can. J. For. Res. 2019, 49, 1124-1134. [CrossRef]

71. van de Voorde, T.F.J.; Bezemer, T.M.; Groenigen, J.W.V.; Jeffery, S.; Mommer, L. Soil biochar amendment in a nature restoration area: Effects on plant productivity and community composition. Ecol. Appl. 2014, 24, 1167-1177. [CrossRef]

72. Bhattacharjee, J.; Taylor, J.P.; Smith, L.M.; Haukos, D.A. Seedling competition between native cottonwood and exotic saltcedar: Implications for restoration. Biol. Invasions 2009, 11, 1777-1787. [CrossRef]

73. Li, W.; Luo, J.; Tian, X.; Soon Chow, W.; Sun, Z.; Zhang, T.; Peng, S.; Peng, C. A new strategy for controlling invasive weeds: Selecting valuable native plants to defeat them. Sci. Rep. 2015, 5, 11004. [CrossRef]

74. Mangla, S.; Sheley, R.L.; James, J.J.; Radosevich, S.R. Intra and interspecific competition among invasive and native species during early stages of plant growth. Plant Ecol. 2011, 212, 531-542. [CrossRef]

75. Witkowski, E.T.F. Growth and competition between seedlings of Protea repens (L.) L. and the alien invasive, Acacia saligna (Labill.) Wendl. in relation to nutrient availability. Funct. Ecol. 1991, 5, 101-110. [CrossRef]

76. Daehler, C.C. Performance comparisons of co-occurring native and alien invasive plants: Implications for conservation and restoration. Annu. Rev. Ecol. Evol. Syst. 2003, 34, 183-211. [CrossRef]

77. Lowe, P.N.; Lauenroth, W.K.; Burke, I.C. Effects of nitrogen availability on competition between Bromus tectorum and Bouteloua gracilis. Plant Ecol. 2003, 167, 247-254. [CrossRef]

78. Zhang, H.; Chang, R.; Guo, X.; Liang, X.; Wang, R.; Liu, J. Shifts in growth and competitive dominance of the invasive plant Alternanthera philoxeroides under different nitrogen and phosphorus supply. Environ. Exp. Bot. 2017, 135, 118-125. [CrossRef]

79. Normand, F.; Habib, R. Nitrogen fertilisation induces floriferous flush in strawberry guava (Psidium cattleianum). Agronomie 2001, 21, 735-742. [CrossRef]

80. Clough, T.J.; Condron, L.M.; Kammann, C.; Müller, C. A Review of Biochar and Soil Nitrogen Dynamics. Agronomy 2013, 3 , 275-293. [CrossRef]

81. Adams, M.M.; Benjamin, T.J.; Emery, N.C.; Brouder, S.J.; Gibson, K.D. The effect of biochar on native and invasive prairie plant species. Invasive Plant Sci. Manag. 2013, 6, 197-207. [CrossRef]

82. Chiriboga, M.; Guo, H.; Campos-Herrera, R.; Röder, G.; Imperiali, N.; Keel, C.; Maurhofer, M.; Turlings, T.C.J. Root-colonizing bacteria enhance the levels of (E)- $\beta$-caryophyllene produced by maize roots in response to rootworm feeding. Oecologia 2018, 187, 459-468. [CrossRef]

83. Köllner, T.G.; Held, M.; Lenk, C.; Hiltpold, I.; Turlings, T.C.J.; Gershenzon, J.; Degenhardt, J. A maize (E)- $\beta$-caryophyllene synthase implicated in indirect defense responses against herbivores is not expressed in most American maize varieties. Plant Cell 2008, 20, 482-494. [CrossRef] [PubMed]

84. Gale, N.V.; Thomas, S.C. Dose-dependence of growth and ecophysiological responses of plants to biochar. Sci. Total Environ. 2019, 658, 1344-1354. [CrossRef]

85. Rajkovich, S.; Enders, A.; Hanley, K.; Hyland, C.; Zimmerman, A.R.; Lehmann, J. Corn growth and nitrogen nutrition after additions of biochars with varying properties to a temperate soil. Biol. Fertil. Soils 2012, 48, 271-284. [CrossRef]

86. Gale, N.V.; Thomas, S.C. Spatial heterogeneity in soil pyrogenic carbon mediates tree growth and physiology following wildfire. J. Ecol. 2021, 109, 1479-1490. [CrossRef] 